\title{
Antioxidant properties of some plants growing wild in Turkey
}

\author{
By A. Serteser, ${ }^{1}$ M. Kargıoğlu, ${ }^{1}$ V. Gök, ${ }^{2}$ Y. Bağcı, ${ }^{3}$ M. Musa Özcan ${ }^{4^{*}}$ and D. Arslan ${ }^{4}$
}

\author{
${ }^{1}$ Faculty of Science and Education, Department of Biology, Afyon Kocatepe University, \\ Afyonkarahisar, Turkey \\ ${ }^{2}$ Faculty of Engineering, Department of Food Engineering, Afyon Kocatepe University, \\ Afyonkarahisar, Turkey \\ ${ }^{3}$ Department of Biology, Faculty of Science and Education, Selcuk University, Konya,Turkey \\ ${ }^{4}$ Department of Food Engineering, Faculty of Agricultural, Selcuk University, Konya, Turkey
}

$\left({ }^{*}\right.$ Corresponding author: mozcan @ selcuk.edu.tr)

\begin{abstract}
RESUMEN
Propiedades antioxidantes de algunas plantas que crecen salvajes en Turquía.

En este estudio, la actividad antioxidante de extractos metanólicos al $50 \%$ en agua de 38 plantas que crecen en la provincia turca de Afyonkarahisar fueron evaluados con algunos ensayos antioxidantes, incluyendo la actividad captadora de radicales libres y de peróxido de oxígeno $\left(\mathrm{H}_{2} \mathrm{O}_{2}\right)$ y la actividad quelatante de metales $\left(\mathrm{Fe}^{2+}\right)$. Los extractos metanólicos de frutas de las especies Cornus y Morus (actividades captadoras de $\mathrm{H}_{2} \mathrm{O}_{2}$ y DPPH y actividad quelatante de $\mathrm{Fe}^{2+}$ ) y los extractos metanólicos de hojas de especies de Mentha (actividad captadora de DPPH) son los que mostraron una actividad mayor. Estas propiedades antioxidantes dependieron de la concentración de la muestra.
\end{abstract}

PALABRAS-CLAVE: Actividad antioxidante - Actividad quelatante - Captadores radicalarios - Extractos - Plantas medicinales y aromáticas.

\section{SUMMARY}

Antioxidant properties of some plants growing wild in Turkey.

In this study, the antioxidant activity of $50 \%$ aqueous methanol extracts of 38 plants growing in the Afyonkarahisar province of Turkey were evaluated by various antioxidant assay, including free radical scavenging, hydrogen peroxide $\left(\mathrm{H}_{2} \mathrm{O}_{2}\right)$ scavenging and metal $\left(\mathrm{Fe}^{2+}\right)$ chelating activities. The methanolic fruit extracts of the Cornus and Morus species $\left(\mathrm{H}_{2} \mathrm{O}\right.$ and $\mathrm{DPPH}$ scavenging activities, $\mathrm{Fe}^{2+}$ chelating activity) and the methanolic leaf extracts of the Mentha species (DPPH scavenging activities) examined in the assay showed the strongest activities. These antioxidant properties depended on the concentration of samples.

KEY-WORDS: Antioxidant activity - Chelating activities Extracts - Medicinal and aromatic plants - Radical scavenging.

\section{INTRODUCTION}

Fruits, vegetables and herbs are recommended at present as optimal sources of chemical constituents with antioxidant activity and supplementing the human diet with plants containing high amounts of compounds capable of deactivating free radicals may have beneficial effects (Madsen and Bertelsen, 1995, Velioglu, Mazza, Gao and Oomah, 1998; Lutomski, 2001).

Antioxidants are compounds which prevent some toxic materials in the body, especially free radicals. Free radicals which lead to oxidation are basically oxygen sourced metabolites (super oxide anions $\mathrm{O}_{2}$, hydrogen peroxide $\mathrm{H}_{2} \mathrm{O}_{2}$, hydroxide radical $(\mathrm{OH})^{2}$, hypochloric acid, chloramines, nitrogen dioxide, ozone and lipid peroxides. Antioxidants such as beta, carotene, ascorbic acid, and alfa- tocopherol are proven to prevent the oxidation of free radicals by in vitro and in vivo studies (Cross et al. 1987; Aruoma, 1998; Peter, 1993; Brand-Williams et al. 1995; Stone and Papas, 1997; Zheng and Wang, 2001; Gümrükçüo lu, 2003). Vitamin A takes part in the regulation of protective epitel in the lungs, stomach, urinary tract and other organs in the defense mechanism of the human body. Another antioxidant, tocopherol, protects cells from free radicals, heavy metals, poisonous compounds, medicines and radiation by stabilizing lipid parts of the cell membrane and transporting molecules. Tocopherols prevent the degenerative effects of free radicals in tissue, skin and blood vessels. Another antioxidant, ascorbic acid (Vitamin C) aids in the growth and well being of the body's cells in bones, ligaments and blood vessels. Besides, it helps the body to respond against infections and stress and assists in the proper use of iron (Cross et al. 1987; Aruoma, 1998; Peter, 1993; Brand-Williams et al. 1995; Stone and Papas, 1997; Zheng and Wang, 2001; Gümrükçüoğlu, 2003).

Afyonkarahisar is rich in a wide variety of flora and vegetation. This richness in flora and vegetation is especially notable in Sultan, Emir, Akda and the Kumalar Mountains. For this reason, many native and foreign botanists collected plant samples from these mountains and other locations in Afyonkarahisar (Akçiçek, 2003).

Afyonkarahisar is in the middle zone of the Mediterranean and the İran-Turan floristic regions 
from the point of view of plant geography and there are plants which also represent the Europa-Syberia flouristic region. Around Afyonkarahisar, there are approximately 2500 natural plant species, almost 350 of them endemic, because of its ecological conditions and especially its microclimate (Akçiçek, 2003; Kargıoğlu, 2003; Köse and Ocak, 2004).

The aim of the present work is to investigate the antioxidant properties of some plants growing wild in the Afyonkarahisar province of Turkey.

\section{MATERIALS AND METHODS}

\subsection{Materials}

Plants (Taxus baccata L., Pistacia terebinthus L. subsp. palaestina (Boiss.) Engler, Pistacia terebinthus L. subsp. terebinthus, Rhus coriaria L., Artemisia campestris L., Artemisia santonicum L., Berberis crataegina DC., Berberis integerrima Bunge, Berberis vulgaris L., Gypsophila eriocalyx Boiss., Gypsophila parva Barkoudah, Gypsophila perfoliata L., Gypsophila pilosa Hudson, Gypsophila tubulosa (Jaub. \& Spach) Boiss., Euonymus latifolius (L.) Mill. subsp. latifolius, Cistus laurifolius L., Cornus mas L., Cornus sanguinea L. subsp. australis (C. A. Mey.) Jav., Cornus sanguinea L. subsp. sanguinea, Mentha aquatica L., Mentha longifolia (L.) Huds. subsp. Iongifolia, Mentha longifolia L. subsp. typhoides (Briq.) Harley var. typhoides, Mentha pulegium L., Mentha spicata L. subsp. spicata, Mentha spicata L. subsp. tomentosa (Briq.) Harley, Ficus carica L. subsp. carica, Jasminum fruticans L., Achillea teretifolia Willd., Morus alba L., Morus nigra L., Cerasus mahaleb (L.) Miller var. mahaleb, Prunus divaricata Ledeb. subsp. divaricata, Sorbus torminalis (L.) Crantz var. torminalis, Sorbus torminalis (L.) Crantz var. pinnatifida Boiss., Chenopodium foliosum (Moench) Asch., Pyrus elaeagnifolia Pall. subsp. elaeagnifolia, Pyrus elaeagnifolia Pallas subsp. kotschyana (Boiss.) Browicz, Viburnum lantana L., Malus sylvestris Mill. subsp. orientalis (Uglitzk.) Browicz var. Orientalis) were obtained from several locations of the Afyonkarahisar province in Turkey in early spring, 2007 . Materials from different periods were brought in Poly Vinyl Chloride containers. Samples were kept in sealed containers at $-18^{\circ} \mathrm{C}$ during the study.

\subsection{Preparation of extracts}

The aerial parts of plants were dried in the shade at room temperature. About $2.5 \mathrm{~g}$ from each dried plant sample were extracted by homogenizing in a mixer (Ultra turrax) with $50 \mathrm{ml}$ solvent $(50 \%$ water-methanol). The extracts were centrifuged at $4000 \times \mathrm{xg} 3 \mathrm{~min}$ at $4{ }^{\circ} \mathrm{C}$ (Hettich Zentrfügen-Universal $32 \mathrm{R}$ ) after draining through coarse filter paper. The filtrate volume was completed to $50 \mathrm{ml}$ and drained through blue band filter paper (No 589). The filtrats were stored at $4{ }^{\circ} \mathrm{C}$ until analysis.

\subsection{Methods}

\section{Free radical scavenging effect}

The radical scavenging activity against the DPPH radical was evaluated according to the method of Brand-Williams et al. (1995) and Lim and Murtijaya (2007) with some minor modifications. The assay mixture contained $1.5 \mathrm{ml}$ of a $0.09 \mathrm{mg} / \mathrm{ml}$ of DPPH (Sigma Chem, Co, Str. Lous, USA) in methanol, $1 \mathrm{ml}$ of acetate buffer solution (100 mM, pH 5.5). The dilutions between 0.4 to $4 \mathrm{mg} / \mathrm{ml}$ were prepared with methanol. $3.9 \mathrm{ml}$ DPPH solution prepared with $6 \times$ $10^{-5} \mathrm{M}$ (molar) methanol was added to each $0.1 \mathrm{ml}$ of dilutions and shaken well. The mixture was prepared and incubated for $60 \mathrm{~min}$ at room temperature in the dark. The absorbance of the remaining DPPH was determined at $517 \mathrm{~nm}$ against a blank. The scavenging activity was expressed as IC50 $(\mathrm{mg} / \mathrm{ml})$. All analyses were carried out in duplicate. Linear regression equations of absorbance against concentration were determined by measuring the absorbance of seven different concentrations of DPPH $\left(6 \times 10^{-5} \mathrm{M}\right)$ stock solution.

$\mathrm{A}(515 \mathrm{~nm})=17.692(\mathrm{C} \mathrm{DPPH})-0.0216\left(\mathrm{R}^{2}=\right.$ $=0.9896)$

The remained DPPH concentrations against absorbance values of the sample series of different concentrations were calculated and then the remaining DPPH percentage was calculated:

$\%$ Remaining DPPH = [DDPH] sample / [DPPH] control

The exponential regression equation was determined between the rate of the remaining DPPH percentage and the DDPH amount of sample in vitro and sample concentrations of plants which decreased their initial DPPH concentrations by $50 \%$ (efficient concentration $\left[\mathrm{EC}_{50}\right]$ ). Antiradical activity $(A E)$ was calculated by dividing $E C_{50}$ values into 1.

\section{$\mathrm{Fe}^{+2}$ chelating activity}

Modified methods of Lim and Murtijaya (2007) were used for the determination of $\mathrm{Fe}^{+2}$ chelating activities of samples. $1 \mathrm{ml}$ of extract with different concentrations between $6-45 \mathrm{mg} / \mathrm{ml}$ and $3.7 \mathrm{ml}$ deionized water were mixed. A $0.1 \mathrm{ml} 2 \mathrm{mM} \mathrm{FeCl}_{2}$ solution was added, shaken and kept in the dark at room temperatures for $70 \mathrm{~min}$. Then, $0.2 \mathrm{ml}$ $5 \mathrm{mM}$ ferrozin were added and shaken again and the absorbance of obtained $\mathrm{Fe}^{+2}$-ferrozin complex after 10min was measured at $562 \mathrm{~nm}$. 1 $\mathrm{ml}$ water was used instead of the sample for the control. The equation is given below (Yen and Wu, 1999).

Chelating activity $(\%)=[1-$ (absorbance of sample / absorbance of control) $] \times 100$

\section{$\mathrm{H}_{2} \mathrm{O}_{2}$ inhibition effect}

The $\mathrm{H}_{2} \mathrm{O}_{2}$ inhibition effect of spice and plant extracts can be determined by spectrophotometer 
(Ruch et al. 1989). $1 \mathrm{ml}$ (2.6 and $10 \mathrm{mg} / \mathrm{ml}$ ) sample, $3.4 \mathrm{ml} 0.1 \mathrm{M}$ phosphate buffer $(\mathrm{pH} 7.4)$ and $0.6 \mathrm{ml} 43 \mathrm{mM} \mathrm{H}_{2} \mathrm{O}_{2}$ were mixed and after 60 minutes the absorbance of the mixture was measured at $230 \mathrm{~nm}$. Control solutions without $\mathrm{H}_{2} \mathrm{O}_{2}$ were prepared for each sample concentration. To determine the $\mathrm{H}_{2} \mathrm{O}_{2} \mathrm{mM}$ concentration which did not involve the reaction, a linear repression equation was used. $3.4 \mathrm{ml}$ phosphate buffer were added to $0.6 \mathrm{ml} \mathrm{10,15,} \mathrm{25,}$ 43 and $50 \mathrm{mM} \mathrm{H}_{2} \mathrm{O}_{2}$ at $230 \mathrm{~nm}$. Linear regression equations were obtained by the diagram of concentration against absorbance.

$A(230)=0.0104 \times C\left(\mathrm{H}_{2} \mathrm{O}_{2}, \mathrm{mM}\right)+0.0814\left(\mathrm{R}^{2}=\right.$ $=0.9766)(+)$ - catechin was used as reference antioxidant. The following equation was used;

$\mathrm{H}_{2} \mathrm{O}_{2}$ inhibition capacity $(\%)=\left[1-\left(\mathrm{H}_{2} \mathrm{O}_{2}\right.\right.$ conc. of sample $/ \mathrm{H}_{2} \mathrm{O}_{2}$ conc. of control )] $\times 100$

\section{Statistical analyses}

Results of the research were analyzed for statistical significance by analysis of variance (Püskülcü and İkiz, 1989). This research was performed in three duplicates with a replicate.

\section{RESULTS AND DISCUSSION}

\subsection{Free radical scavenging activity}

DPPH, as a partially organic radical, is used to determine the antioxidant activities of many plant extracts and compounds (Brand-Williams et al.1995). This method is based on a decrease in alcoholic DPPH solution in the presence of $\mathrm{H}$ binding antioxidant (DPPH ${ }^{\cdot}+\mathrm{AH} \rightarrow \mathrm{DPPH}-\mathrm{H}+$ $\left.+A^{*}\right)$. A DPPH solution is dark violet colored and has a strong absorption range at $517 \mathrm{~nm}$. It loses its color when transformed to $\mathrm{DPPH}-\mathrm{H}$ and the absorption level decreases. This decrease in absorption shows the cytochiometric decrease in DPPH.

The DPPH radical scavenging effects of plant leaf and fruit extracts are given in Tables 1 and 2, respectively. While the antiradical activity of the leaf extracts of plants varies from 0.258 (Gypsophila pilosa) to 0.693 (Cornus sanguinea L. subsp. australis), the activities of fruit extracts range from 0.503 (Taxus baccata) to 0.928 (Cornus mas). Generally, the antiradical activity of fruit extracts was found higher than those of leaf extracts. This effect is probably due to the high phenolic compound contents of fruit extracts. The antiradical

Table 1

DPPH radical scavenging effects of plant (leaves) extracts *

\begin{tabular}{|c|c|c|}
\hline Sample & $\mathrm{EC}_{50}$ & $A E$ \\
\hline Artemisia campestris $\mathrm{L}$. & 2.467 & $0.405 \pm 0.03$ defg \\
\hline Artemisia santonicum L. & 2.498 & $0.400 \pm 0.06$ defg \\
\hline Berberis crataegina DC. & 2.145 & $0.466 \pm 0.04 \mathrm{cde}$ \\
\hline Berberis integerrima Bunge & 2.423 & $0.413 \pm 0.08$ defg \\
\hline Berberis vulgaris $\mathrm{L}$. & 2.374 & $0.421 \pm 0.04$ defg \\
\hline Cistus laurifolius L. & 2.892 & $0.345 \pm 0.03 \mathrm{efg}$ \\
\hline Cornus mas L. & 1.398 & $0.716 \pm 0.07 \mathrm{a}$ \\
\hline Cornus sanguinea L. subsp. australis (C. A. Mey.) Jav. & 1.442 & $0.693 \pm 0.02 a b$ \\
\hline Cornus sanguinea $\mathrm{L}$. subsp. Sanguinea & 1.487 & $0.672 \pm 0.08 \mathrm{ab}$ \\
\hline Euonymus latifolius (L.) Mill. subsp. Latifolius & 2.421 & $0.413 \pm 0.05$ defg \\
\hline Ficus carica L. subsp. Carica & 1.822 & $0.549 \pm 0.04 \mathrm{bcd}$ \\
\hline Gypsophila eriocalyx Boiss. & 3.678 & $0.272 \pm 0.05 \mathrm{fg}$ \\
\hline Gypsophila parva Barkoudah & 3.453 & $0.290 \pm 0.02 \mathrm{fg}$ \\
\hline Gypsophila perfoliata L. & 3.126 & $0.320 \pm 0.09 \mathrm{efg}$ \\
\hline Gypsophila pilosa Hudson & 3.873 & $0.258 \pm 0.07 \mathrm{~g}$ \\
\hline Gypsophila tubulosa (Jaub. \& Spach) Boiss. & 3.098 & $0.323 \pm 0.06 \mathrm{efg}$ \\
\hline Jasminum fruticans $\mathrm{L}$. & 1.904 & $0.525 \pm 0.07 \mathrm{bcd}$ \\
\hline Mentha aquatica $\mathrm{L}$. & 1.634 & $0.612 \pm 0.04 \mathrm{abc}$ \\
\hline $\begin{array}{l}\text { Mentha longifolia (L.) Huds. subsp. Longifolia } \\
\text { Mentha Iongifolia (L.) Huds. subsp. typhoides (Briq.) }\end{array}$ & 1.678 & $0.596 \pm 0.06 \mathrm{abc}$ \\
\hline Harley var. Typhoides & 1.612 & $0.620 \pm 0.05 a b c$ \\
\hline Mentha pulegium $\mathrm{L}$. & 1.516 & $0.659 \pm 0.08 \mathrm{ab}$ \\
\hline Mentha spicata L. subsp. Spicata & 1.656 & $0.604 \pm 0.04 \mathrm{abc}$ \\
\hline Mentha spicata L. subsp. tomentosa (Briq.) Harley & 1.714 & $0.583 \pm 0.03 \mathrm{abc}$ \\
\hline Pistacia terebinthus L .subsp. palaestina (Boiss.) Engler & 3.214 & $0.311 \pm 0.02 \mathrm{efg}$ \\
\hline Pistacia terebinthus L. subsp. Terebinthus & 2.972 & $0.336 \pm 0.01 \mathrm{efg}$ \\
\hline Rhus coriaria L. & 2.356 & $0.424 \pm 0.05$ def \\
\hline Taxus baccata L. & 3.456 & $0.289 \pm 0.01 \mathrm{fg}$ \\
\hline
\end{tabular}

${ }^{a}$ Efficiency coefficient $\left(E_{50}\right)$ (mg sample / $\left.\mathrm{mg} \mathrm{DPPH}\right)$ :sample amount needed to decrease the DPPH concentration at the beginning by $50 \%,{ }^{b}$ Antiradical activity $(\mathrm{AE}): 1 / \mathrm{EC}_{50}$.

* mean \pm standard deviation. 
Table 2

DPPH radical scavenging effects of plant (fruit) extracts *

\begin{tabular}{lll}
\hline \multicolumn{1}{c}{ Sample } & $\mathrm{EC}_{50}$ & $\mathrm{AE}$ \\
\hline Achillea teretifolia Willd. & 1.765 & $0.567 \pm 0.04 \mathrm{efgh}$ \\
Berberis crataegina DC. & 1.345 & $0.743 \pm 0.12 \mathrm{bcde}$ \\
Berberis integerrima Bunge & 1.412 & $0.708 \pm 0.06 \mathrm{bcdefg}$ \\
Berberis vulgaris L.. & 1.456 & $0.687 \pm 0.16 \mathrm{cdefgh}$ \\
Cerasus mahaleb (L.) Miller var. Mahaleb & 1.645 & $0.608 \pm 0.04 \mathrm{efgh}$ \\
Chenopodium foliosum (Moench) Asch. & 1.458 & $0.686 \pm 0.12 \mathrm{cdefgh}$ \\
Cistus laurifolius L. & 1.724 & $0.580 \pm 0.08 \mathrm{efgh}$ \\
Cornus mas L. & 1.078 & $0.928 \pm 0.13 \mathrm{a}$ \\
Cornus sanguinea L. subsp. australis (C. A. Mey.) Jav. & 1.156 & $0.865 \pm 0.09 \mathrm{abc}$ \\
Cornus sanguinea L. subsp. Sanguinea & 1.205 & $0.829 \pm 0.14 \mathrm{abcd}$ \\
Euonymus latifolius (L.) Mill. subsp. Latifolius & 1.646 & $0.608 \pm 0.06 \mathrm{efgh}$ \\
Ficus carica L. subsp. Carica & 1.562 & $0.640 \pm 0.07 \mathrm{defgh}$ \\
Jasminum fruticans L. & 1.876 & $0.533 \pm 0.03 \mathrm{gh}$ \\
Malus sylvestris Mill. subsp. orientalis (Uglitzk.) & & \\
Browicz var. Orientalis & 1.367 & $0.732 \pm 0.12 \mathrm{bcdef}$ \\
Morus alba L. & 1.123 & $0.890 \pm 0.05 \mathrm{ab}$ \\
Morus nigra L. & 1.212 & $0.825 \pm 0.10 \mathrm{abcd}$ \\
Pistacia terebinthus L. subsp. palaestina (Boiss.) Engler & 1.875 & $0.533 \pm 0.07 \mathrm{gh}$ \\
Pistacia terebinthus L. subsp. Terebinthus & 1.912 & $0.523 \pm 0.05 \mathrm{gh}$ \\
Prunus divaricata Ledeb. subsp. Divaricata & 1.692 & $0.591 \pm 0.07 \mathrm{efgh}$ \\
Pyrus elaeagnifolia Pall. subsp. Elaeagnifolia & 1.512 & $0.661 \pm 0.07 \mathrm{defgh}$ \\
Pyrus elaeagnifolia Pallas subsp. kotschyana (Boiss.) Browicz & 1.467 & $0.682 \pm 0.04 \mathrm{cdefgh}$ \\
Rhus coriaria L. & 1.822 & $0.548 \pm 0.08 \mathrm{efgh}$ \\
Sorbus torminalis (L.) Crantz var. pinnatifida Boiss. & 1.874 & $0.534 \pm 0.09 \mathrm{gh}$ \\
Sorbus torminalis (L.) Crantz var. torminalis & 1.842 & $0.543 \pm 0.04 \mathrm{fgh}$ \\
Taxus baccata L. & 1.986 & $0.503 \pm 0.08 \mathrm{~h}$ \\
Viburnum lantana L. & 1.523 & $0.657 \pm 0.09 \mathrm{defgh}$ \\
\hline
\end{tabular}

${ }^{a}$ Efficiency coefficient $\left(E_{50}\right)$ (mg sample / $\mathrm{mg}$ DPPH): sample amount needed to decrease the DPPH concentration at the beginning by $50 \%,{ }^{\mathrm{b}}$ Antiradical activity (AE): $1 / \mathrm{EC}_{50}$

* mean \pm standard deviation.

activity of Cornus spp. and Morus spp were compared to those of other fruit extracts (Table 2). These plant extracts may be accepted as having a higher $\mathrm{H}$ binding capacity against the DPPH radical. The lowest AEs are obtained from Gypsophila eriocalyx Boiss (0.272), Gypsophila pilosa Hudson (0.258) species and Gypsophila parva Barkoudah.

The highest DPPH radical scavenging effects were determined in the fruit extracts of Cornus and Morus species with values which varied from 1.078$1.212\left(\mathrm{EC}_{50}\right)$. The fruit extracts of Taxus baccata $\mathrm{L}$., Pistacia terebinthus L .subsp. palaestina (Boiss.) Engler and Pistacia terebinthus L. subsp. terebinthus, Sorbus species and Jasminum fruticans $\mathrm{L}$. plants showed the lowest DPPH radical scavenging effects.

Termentzi et al. (2006) reported the AE values (DPPH radical scavenging) of the methanol extracts of fruit pulp from ripe Sorbus domestica fruits as 0.682 . Tural and Koca (2008) reported that the methanolic extracts of the Cornelian cherry (Cornus mas L.) fruits showed $\mathrm{EC}_{50}(\mathrm{mg} / \mathrm{ml})$ (DPPH reduction) values as 0.52 . Topçu et al. (2007) reported that the methanol extracts of Pistacia terebinthus fruits showed activity as high as the standard, at $50 \mu \mathrm{g} / \mathrm{ml}$ as $95 \%$ for DPPH scavenging effect, \%). Bae and Suh (2007) reported the scavenging abilities of DPPH radicals of the ethanolic extracts of five major cultivars of mulberry fruits (Morus alba L.) from Korea, as between 225.9-537.6 $\mu \mathrm{g} \quad\left(\mathrm{IC}_{50}\right)$. Effective scavenging concentration $\left(\mathrm{EC}_{50}\right)$ on $\mathrm{DPPH}$ radicals was 0.70 $\mu \mathrm{g} / \mathrm{ml}$ in ethyl acetate and tannin fractions and 5.33 $\mu \mathrm{g} / \mathrm{ml}$ in the anthocyanin rich fraction of sumac extracts (Koflar et al. 2007). Emami, Asili, Mohaghegbi \& Hassanzadeh (2007) reported that the methanol extracts of the leaves of Taxus baccata L. from Armaniolan, Arasbaran and East Azerbayejan, contained high amounts of alkaloids, tannins and flavonoids while the fruit extracts contained high amounts of tannins and these extracts possessed high antioxidant activity (\%) as approximately 90, using the TBA method. According to Cao et al. (1996) among the 22 common vegetables studied, garlic had the highest antioxidant activity, with an antioxidant score (automated oxygen radical absorbance capacity assay) of 23.2 based on fresh weight of the vegetable. However, according to Miller et al. (2000), garlic is very high in antioxidants, its activity being about sixfold that of yellow onion (1300 Trolox equivalents/100 g vs. 200 Trolox equivalents /100 g). The difference is probably at least partially due to the different methods used. The radical scavenging and antioxidant results for blackcurrant plants obtained in this study are not in agreement with the earlier literature (Cao et al.,1996; Gazzani et al.,1998). However these contradictory results 
are most likely due to differences in methodology and experimental conditions used in the different studies. Due to the wide wariety of potential antioxidant compounds, such as vitamins, flavonoids, phenolic acids and sulphur compounds present in plants, differences in the method of sample extraction can results in a wide variation in the antioxidant activity of the extract (Nuutila et al. 2003).

The radical scavenging and antioxidant activity results for these plants show some differences from the earlier reported results above. However these contradictory results are most likely due to differences in methodology and experimental conditions used in the different studies. Due to the wide variety of potential antioxidant compounds, such as vitamins, flavonoids, phenolic acids and sulphur compounds present in plants, differences in the method of sample extraction can results in a wide variation in the antioxidant activity of the extract (Nuutila, Puupponen-Pimia, Aarni \& Oksman-Caldentey, 2003). In our study, there was a noticeable correlation between high radical scavenging / antioxidant activity and high amounts of total phenolics. More plants have been used as a source of food, remedy and animal fodder in Turkey (Baytop, 1984). The antioxidant activities of spices and herbs are attributed to their polar phenolic and essential oil contents (Tsimidou and Boskou, 1994; Shahidi, 1997; Özkan and Özcan, 2006).

\section{2. $\mathrm{Fe}^{+2}$ chelating activity}

Chelating agents may have great importance for rancidity of oily foods; even though they are not antioxidant materials. Because iron catalyzes this reaction during lipid peroxidation, Ferrozin forms a complex with $\mathrm{Fe}^{+2}$. The amounts of complex and red color decrease in the presence of the other chelating agents. A decrease in absorption values can be determined by changes in the color. The decrease in absorption shows the effectiveness of chelating agent added with the exception of ferrozin.

Table 3 and 4 show the chelating activities of plant leaf and fruit extracts. The $\mathrm{Fe}^{2+}$ chelating activity of fruit extracts of plants was established as higher than that of leaf extracts. The highest chelating activity was found in Cornus mas fruit extracts. The Chelating activities of Cornus spp. fruit extracts were found higher compared with other fruit extracts (Table 4). The highest chelating activity was observed in the Cornus species ranging from $44.64-45.72 \%$. The lowest chelating activities were obtained from the Gypsophila species (16.34$20.32 \%)$, Taxus baccata L. (18.93\%) and Pistacia terebinthus L .subsp. palaestina (Boiss.) Engler (19.26\%).

The highest $\mathrm{Fe}^{+2}$ chelating activity was determined in the fruit extracts of the Cornus species; while the lowest values belong to the Pistacia species

Table 3

$\mathrm{Fe}^{2+}$ chelating activity (\%)of plant (leaves) extracts

\begin{tabular}{ll}
\hline \multicolumn{1}{c}{ Sample } & Chelating activity (\%) \\
\hline Artemisia campestris L. & $25,42 \pm 1,63 \mathrm{ij}$ \\
Artemisia santonicum L. & $26,02 \pm 2,01 \mathrm{hi}$ \\
Berberis crataegina DC. & $28,36 \pm 2,45 \mathrm{fghi}$ \\
Berberis integerrima Bunge & $27,12 \pm 2,9 \mathrm{fghi}$ \\
Berberis vulgaris L. & $28,02 \pm 2,71 \mathrm{fghi}$ \\
Cistus laurifolius L. & $28,43 \pm 2,79 \mathrm{fghi}$ \\
Cornus mas L. & $45,72 \pm 3,55 \mathrm{a}$ \\
Cornus sanguinea L. subsp. australis (C. A. Mey.) Jav. & $44,64 \pm 3,58 \mathrm{ab}$ \\
Cornus sanguinea L. subsp. sanguinea & $44,92 \pm 3,86 \mathrm{ab}$ \\
Euonymus latifolius (L.) Mill. subsp. latifolius & $30,26 \pm 2,58 \mathrm{fghi}$ \\
Ficus carica L. subsp. carica & $32,86 \pm 1,96 \mathrm{efg}$ \\
Gypsophila eriocalyx Boiss. & $17,34 \pm 2,2 \mathrm{k}$ \\
Gypsophila parva Barkoudah & $19,32 \pm 1,99 \mathrm{k}$ \\
Gypsophila perfoliata L. & $20,32 \pm 2,54 \mathrm{jk}$ \\
Gypsophila pilosa Hudson & $16,34 \pm 1,80 \mathrm{k}$ \\
Gypsophila tubulosa (Jaub. \& Spach) Boiss. & $18,51 \pm 1,79 \mathrm{k}$ \\
Jasminum fruticans L. & $31,24 \pm 1,71 \mathrm{fgh}$ \\
Mentha aquatica L. & $38,96 \pm 2,2 \mathrm{~cd}$ \\
Mentha longifolia (L.) Huds. subsp. longifolia & $37,23 \pm 2,13 \mathrm{cde}$ \\
Mentha longifolia (L.) Huds. subsp. typhoides (Briq.) Harley var. typhoides & $38,23 \pm 2,8 \mathrm{~cd}$ \\
Mentha pulegium L. & $40,22 \pm 3,54 \mathrm{bc}$ \\
Mentha spicata L. subsp. spicata & $39,64 \pm 2,12 \mathrm{bcd}$ \\
Mentha spicata L. subsp. tomentosa (Briq.) Harley & $34,42 \pm 2,24 \mathrm{def}$ \\
Pistacia terebinthus L .subsp. palaestina (Boiss.) Engler & $19,26 \pm 1,76 \mathrm{k}$ \\
Pistacia terebinthus L. subsp. terebinthus & $24,65 \pm 2,28 \mathrm{ij}$ \\
Rhus coriaria L. & $26,34 \pm 2,51 \mathrm{hi}$ \\
Taxus baccata L. & $18,93 \pm 1,63 \mathrm{k}$ \\
\hline
\end{tabular}

* mean \pm standard deviation. 
Table 4

$\mathrm{Fe}^{2+}$ chelating activity (\%)of plant (fruit) extracts

\begin{tabular}{ll}
\hline \multicolumn{1}{c}{ Sample } & Chelating activity (\%) \\
\hline Achillea teretifolia Willd. & $32,96 \pm 3,04 \mathrm{ijkl}$ \\
Berberis crataegina DC. & $44,76 \pm 2,76 \mathrm{cdef}$ \\
Berberis integerrima Bunge & $43,65 \pm 3,05 \mathrm{def}$ \\
Berberis vulgaris L.. & $42,98 \pm 3,99 \mathrm{ef}$ \\
Cerasus mahaleb (L.) Miller var. mahaleb & $35,49 \pm 2,27 \mathrm{ghijk}$ \\
Chenopodium foliosum (Moench) Asch. & $43,76 \pm 2,90 \mathrm{def}$ \\
Cistus laurifolius L. & $36,27 \pm 4,42 \mathrm{ghij}$ \\
Cornus mas L. & $54,24 \pm 3,41 \mathrm{a}$ \\
Cornus sanguinea L. subsp. australis (C. A. Mey.) Jav. & $52,34 \pm 2,54 \mathrm{ab}$ \\
Cornus sanguinea L. subsp. sanguinea & $51,24 \pm 4,29 \mathrm{bc}$ \\
Euonymus latifolius (L.) Mill. subsp. latifolius & $38,65 \pm 2,98 \mathrm{fghij}$ \\
Ficus carica L. subsp. carica & $40,69 \pm 2,91 \mathrm{fgh}$ \\
Jasminum fruticans L. & $33,54 \pm 2,68 \mathrm{ijkl}$ \\
Malus sylvestris Mill. subsp. orientalis (Uglitzk.) Browicz var. orientalis & $45,32 \pm 2,46 \mathrm{cdef}$ \\
Morus alba L. & $49,98 \pm 3,69 \mathrm{bcd}$ \\
Morus nigra L. & $48,32 \pm 2,96 \mathrm{bcde}$ \\
Pistacia terebinthus L. subsp. palaestina (Boiss.) Engler & $30,65 \pm 3,13 \mathrm{kl}$ \\
Pistacia terebinthus L. subsp. terebinthus & $29,42 \pm 2,05 \mathrm{kl}$ \\
Prunus divaricata Ledeb. subsp. divaricata & $34,29 \pm 1,41 \mathrm{hijkl}$ \\
Pyrus elaeagnifolia Pall. subsp. elaeagnifolia & $41,83 \pm 3,25 \mathrm{efg}$ \\
Pyrus elaeagnifolia Pallas subsp. kotschyana (Boiss.) Browicz & $43,74 \pm 1,72 \mathrm{def}$ \\
Rhus coriaria L. & $31,82 \pm 2,95 \mathrm{jkl}$ \\
Sorbus torminalis (L.) Crantz var. pinnatifida Boiss. & $32,61 \pm 1,39 \mathrm{ijkl}$ \\
Sorbus torminalis (L.) Crantz var. torminalis & $33,65 \pm 2,39 \mathrm{jjkl}$ \\
Taxus baccata L. & $28,32 \pm 1,67 \mathrm{I}$ \\
Viburnum lantana L. & $39,43 \pm 2,69 \mathrm{fghi}$ \\
\hline
\end{tabular}

* mean \pm standard deviation.

Table 5

$\mathrm{H}_{2} \mathrm{O}_{2}$ inhibition activity of plant (leaves) extracts

\begin{tabular}{ll}
\hline \multicolumn{1}{c}{ Sample } & Inhibition (\%) \\
\hline Artemisia campestris L. & $28,32 \pm 2,87 \mathrm{gh}$ \\
Artemisia santonicum L. & $26,17 \pm 2,26 \mathrm{hi}$ \\
Berberis crataegina DC. & $32,76 \pm 1,78 \mathrm{efg}$ \\
Berberis integerrima Bunge & $30,46 \pm 3,16 \mathrm{fgh}$ \\
Berberis vulgaris L. & $35,54 \pm 2,95 \mathrm{def}$ \\
Cistus laurifolius L. & $41,54 \pm 3,74 \mathrm{bcd}$ \\
Cornus mas L. & $65,42 \pm 5,04 \mathrm{a}$ \\
Cornus sanguinea L. subsp. australis (C. A. Mey.) Jav. & $62,32 \pm 3,82 \mathrm{a}$ \\
Cornus sanguinea L. subsp. sanguinea & $61,28 \pm 4,43 \mathrm{ab}$ \\
Euonymus latifolius (L.) Mill. subsp. Latifolius & $38,03 \pm 3,01 \mathrm{cde}$ \\
Ficus carica L. subsp. carica & $39,62 \pm 2,32 \mathrm{~cd}$ \\
Gypsophila eriocalyx Boiss. & $18,64 \pm 2,80 \mathrm{jkl}$ \\
Gypsophila parva Barkoudah & $25,43 \pm 2,23 \mathrm{hi}$ \\
Gypsophila perfoliata L. & $32,65 \pm 2,33 \mathrm{efg}$ \\
Gypsophila pilosa Hudson & $21,54 \pm 1,98 \mathrm{ijk}$ \\
Gypsophila tubulosa (Jaub. \& Spach) Boiss. & $24,27 \pm 2,22 \mathrm{hij}$ \\
Jasminum fruticans L. & $37,02 \pm 1,63 \mathrm{de}$ \\
Mentha aquatica L. & $46,32 \pm 2,91 \mathrm{~b}$ \\
Mentha longifolia (L.) Huds. subsp. longifolia & $44,29 \pm 2,08 \mathrm{bc}$ \\
Mentha longifolia (L.) Huds. subsp. typhoides (Briq.) Harley var. typhoides & $47,32 \pm 2,70 \mathrm{~b}$ \\
Mentha pulegium L. & $59,22 \pm 4,74 \mathrm{ab}$ \\
Mentha spicata L. subsp. spicata & $54,32 \pm 2,57 \mathrm{ab}$ \\
Mentha spicata L. subsp. tomentosa (Briq.) Harley & $56,31 \pm 3,53 \mathrm{ab}$ \\
Pistacia terebinthus L. subsp. palaestina (Boiss.) Engler & $16,78 \pm 1,76 \mathrm{jkl}$ \\
Pistacia terebinthus L. subsp. terebinthus & $21,67 \pm 2,09 \mathrm{ijk}$ \\
Rhus coriaria L. & $24,41 \pm 2,44 \mathrm{hij}$ \\
Taxus baccata L. & $13,44 \pm 1,36 \mathrm{I}$ \\
\hline
\end{tabular}

${ }^{*}$ mean \pm standard deviation. 
Table 6

$\mathrm{H}_{2} \mathrm{O}_{2}$ inhibition activity of plant (fruit) extracts

\begin{tabular}{ll}
\hline \multicolumn{1}{c}{ Sample } & Inhibition (\%) \\
\hline Achillea teretifolia Willd. & $29,61 \pm 3,85 \mathrm{hijk}$ \\
Berberis crataegina DC. & $59,43 \pm 3,94 \mathrm{~cd}$ \\
Berberis integerrima Bunge & $57,34 \pm 3,31 \mathrm{~d}$ \\
Berberis vulgaris L. & $55,67 \pm 2,82 \mathrm{~d}$ \\
Cerasus mahaleb (L.) Miller var. mahaleb & $31,53 \pm 3,64 \mathrm{ghij}$ \\
Chenopodium foliosum (Moench) Asch. & $59,39 \pm 4,07 \mathrm{~cd}$ \\
Cistus laurifolius L. & $32,79 \pm 2,26 \mathrm{ghi}$ \\
Cornus mas L. & $74,35 \pm 5,24 \mathrm{a}$ \\
Cornus sanguinea L. subsp. australis (C. A. Mey.) Jav. & $71,23 \pm 4,02 \mathrm{ab}$ \\
Cornus sanguinea L. subsp. sanguinea & $69,03 \pm 4,17 \mathrm{ab}$ \\
Euonymus latifolius (L.) Mill. subsp. latifolius & $36,53 \pm 1,66 \mathrm{fgh}$ \\
Ficus carica L. subsp. carica & $47,18 \pm 2,29 \mathrm{e}$ \\
Jasminum fruticans L. & $35,32 \pm 2,94 \mathrm{gh}$ \\
Malus sylvestris Mill. subsp. orientalis (Uglitzk.) Browicz var. orientalis & $61,32 \pm 3,56 \mathrm{~cd}$ \\
Morus alba L. & $66,43 \pm 3,34 \mathrm{bc}$ \\
Morus nigra L. & $66,21 \pm 4,30 \mathrm{bc}$ \\
Pistacia terebinthus L. subsp. palaestina (Boiss.) Engler & $24,65 \pm 3,44 \mathrm{jkl}$ \\
Pistacia terebinthus L. subsp. terebinthus & $23,18 \pm 2,14 \mathrm{kl}$ \\
Prunus divaricata Ledeb. subsp. divaricata & $32,65 \pm 2,09 \mathrm{ghi}$ \\
Pyrus elaeagnifolia Pall. subsp. elaeagnifolia & $54,23 \pm 3,31 \mathrm{~d}$ \\
Pyrus elaeagnifolia Pallas subsp. kotschyana (Boiss.) Browicz & $55,28 \pm 3,70 \mathrm{~d}$ \\
Rhus coriaria L. & $26,92 \pm 1,17 \mathrm{ijkl}$ \\
Sorbus torminalis (L.) Crantz var. pinnatifida Boiss. & $34,32 \pm 2,20 \mathrm{gh}$ \\
Sorbus torminalis (L.) Crantz var. torminalis & $38,94 \pm 3,02 \mathrm{fg}$ \\
Taxus baccata L. & $21,28 \pm 1,84^{*} \mathrm{I}$ \\
Viburnum lantana L. & $43,37 \pm 2,86 \mathrm{ef}$ \\
\hline
\end{tabular}

${ }^{*}$ mean \pm standard deviation.

and Taxus baccata L. Jasminum fruticans L., Rhus coriaria L., Achillea teretifolia Willd. and Sorbus species also had lower $\mathrm{Fe}^{+2}$ chelating activities than the fruit extracts of other plants used in the assay. Chelating agents may have a great importance for rancidity of oily foods, even if they are not antioxidant materials. Because iron catalyzes this reaction during lipid peroxidation (Yen and Duh, 1994).

\section{3. $\mathrm{H}_{2} \mathrm{O}_{2}$ inhibition activity}

This method is used to eliminate $\mathrm{O}^{\circ}{ }^{-}$, even though the superoxide radical anion $\left(\mathrm{O}^{\bullet^{-}}\right)$does not initiate lipid oxidation directly. Super reactive hydroxyl radical $(. \mathrm{OH})$ may be formed from the Fenton reaction $\left(\mathrm{Fe}^{+2}+\mathrm{H}_{2} \mathrm{O}_{2} \rightarrow \mathrm{Fe}^{+3}+\mathrm{OH}^{-}+. \mathrm{OH}\right)$ in the presence of metal ions. For this reason, $\mathrm{H}_{2} \mathrm{O}_{2}$ inhibition activity is an important method for the determination of antioxidant characteristics.

The $\mathrm{H}_{2} \mathrm{O}_{2}$ inhibition activities of plant leaf and fruit extracts are given in Tables 5 and 6 , respectively. The Cornus species showed the highest $\mathrm{H}_{2} \mathrm{O}_{2}$ inhibition values (54.32-65.42\%) while Taxus baccata L. and Pistacia terebinthus L .subsp. palaestina (Boiss.) Engler had the lowest $\mathrm{H}_{2} \mathrm{O}_{2}$ inhibition values at $13.44 \%$ and $16.78 \%$, respectively. The Gypsophila species also showed lower $\mathrm{H}_{2} \mathrm{O}_{2}$ inhibition values (18.64-25.43\%) than the other plant leaf extracts analyzed.

The $\mathrm{H}_{2} \mathrm{O}_{2}$ inhibition activity of plant (fruit) extracts was determined higher than those of leaf extracts (Table 6). The $\mathrm{H}_{2} \mathrm{O}_{2}$ inhibition activities of fruit extracts of Taxus baccata L. and Pistacia species were the lowest among the other fruit extracts (21.28-24.65\%). The fruit extracts of Cornus and Morus species had the highest $\mathrm{H}_{2} \mathrm{O}_{2}$ inhibition activities ranging from $66.21-74.35 \%$.

\section{CONCLUSIONS}

The present study demonstrates the antioxidant potential of some herbs and fruits from Turkey which could protect against free radical damage. The information might be useful for the development of food products and additives with appropriate antioxidant properties. It may be noted that Cornus, Morus and Mentha species examined in the assay (Cornus mas L. Cornus sanguinea L. subsp. australis (C. A. Mey.) Jav., Cornus sanguinea L. subsp. sanguinea, Morus alba L., Morus nigra L., Mentha spicata L. subsp. spicata, Mentha spicata L. subsp. tomentosa (Briq.) Harley) show higher antioxidant activities compared to the other plants studied used.

The highest antiradical activity $(A E)$ was observed in the Cornus and Mentha species with values ranging from $0.549-0.716(\mathrm{P}<0.05)$. These plant extracts may be accepted as having higher $\mathrm{H}$ binding capacity against DPPH radical. The highest DPPH radical scavenging effects were determined in fruit extracts from the Cornus and Morus species 
with values varying from 1.078-1.212 $\left(\mathrm{EC}_{50}\right)$. The highest chelating activity was observed for the Cornus species ranging from $44.64-45.72 \%$. It is believed that the detection of natural antioxidant sources and proper consumption of them in the daily diet or the use of isolated compounds in clinical practices would be beneficial for a healthy life.

\section{ACKNOWLEDGEMENT}

This work was supported by Selçuk University Scientific Research Project (S.Ü.-BAP, KonyaTURKEY).

\section{REFERENCES}

Akçiçek E. 2003. Flora of Kumalar Mountain (Afyon), Turkish J. Botany, 27, 383-420.

Aruoma OI. 1998. Free radicals, oxidative stress and antioxidants in human health and disease, $J$ Am. Oil Chem. Soc. 75, 199-212.

Bae S-H, Suh H-J. 2007. Antioxidant activities of five different mulberry cultivars in Korea. LWT- Food Sci. Technol. 40, 955-962.

Baytop T. 1984. Treathment with Plants in Turkey. İstanbul Univ Publ Nu 3255 İstanbul, Turkey. (in Turkish)

Brand-Williams W, Cuvelier ME, Berset C. 1995. Use of a free radical method to evaluate antioxidant activity. Lebensmittel Wiss. Technol. 28, 25-30.

Cao,G., Sofic,E., Prior,R.L. 1996. Antioxidant capacity of tea and common vegetables. J. Agric. Food Chem. 44, 3426-3431.

Cross CE, Halliwell B, Borish ET. 1987. Oxygen radicals and human disease, Ann International Med. 107, 526545.

Emami S A, Asili J, Mohagheghi Z, Hassanzadeh MK. 2007. Antioxidant Activity of Leaves and Fruits of Iranian Conifers. Advance Access Publication, ecam; 4, 313-319 doi:10.1093/ecam/nem011.

Gazzani,G., Papetti,A., Daglia,M., berte,F, Gregotti,C. 1998. Protective activity of water soluble components of some common diet vegetables on rat liver microsome and the effect of thermal treatment. $J$. Agric. Food Chem. 46, 4123-4127.

Gümrükçüo lu A. 2003. Serbest radikaller, http:// www. genetikbilimi. com /gen / serbest radikaller.htm

Kargıoğlu M. 2003. The flora of Ahırdağı (Afyonkarahisar) and its environs. Turkish J. Botany, 27,357-381.

Koflar M, Bozan B, Temelli F, Baser KHC. 2007. Antioxidant activity and phenolic composition of sumac (Rhus coriaria L.) extracts. Food Chem. 103, 952-959.

Köse Y B, Ocak A. 2004. The flora of the northern part of the Emirda Mountains, Turkish J. Botany 28, 369-390.
Madsen H L, Bertelsen G 1995. Spices as antioxidants. Trends in Food Sci. Technol. 6, 271-277.

Miller,H.E., Rigelhof,F., Marquart,L., Prakash,A., Kanter,M. 2000. Antioxidant content of whole grain breakfast cereals, fruits and vegetables. J. Am. College of Nutr. 19, 1-8.

Nuutila AM, Puupponen-Pimia R, Aarni M, Oksman Caldentey KM 2003. Comparison of antioxidant activities of onion and garlic extracts by inhibition of lipid peroxidation and radical scavenging activity. Food Chem. 81, 485-493.

Özkan G, Özcan M. 2006. Antioxidant tocopherol constituents from some medicinal and aromatic plants. Chem. Nat. Comp. 42, 604-605.

Peter AM. 1993. Yağda Çözünen Vitaminlerin Yapı ve Fonksiyonu. In: Murray RK, Darly KG, Peter AM, Victor WR,ed., Harper'ın Biyokimyası, Barış Kitabevi, İstanbul, 704-714.

Püskülcü H, İkiz F. 1989. Introduction to Statistic. Bilgehan Press, p333, Bornova, İzmir, Turkey. (in Turkish)

Ruch RJ, Cheng SJ, Klaunig JE. 1989. Prevention of cytotoxicity and inhibition of intracellular communication by antioxidant catechins isolated from Chinese green tea. Carcinogenesis 10, 1003-1008.

Shahidi F. 1997. Natural Antioxidants. AOCS Press, Champaign, IL, 11p.

Stone WL, Papas AM. 1997. Tocopherols and the Etiology of Colon Cancer. J. Natl Cancer Inst. 89, 1006-1014.

Termentzi A, Kefalas P, Kokkalou E. 2006. Antioxidant activities of various extracts and fractions of Sorbus domestica fruits at different maturity stages. Food Chem. 98, 599-608.

Topcu G, Ay M, Bilici A, Sarıkurkcu C, Özturk M, Ulubelen A. 2007. A new flavone from antioxidant extracts of Pistacia terebinthus. Food Chem. 103, 816-822.

Tsimidou M, Boskou D. 1994.Spices, Herbs and Edible Fungi, Elsevier, Amsterdam, 272 pp.

Tural S, Koca I. 2008. Physico-chemical and antioxidant properties of cornelian cherry fruits (Cornus mas L.) grown in Turkey. Sci. Hort. 116, 362-366

Velioglu YS, Mazza G, Gao L, Oomah BD. 1998. Antioxidant Activity and total phenolics in selected fruits, vegetables, and grain products. J. Agric. Food Chem. 46, 4113-4117.

Yen, G.C., Duh, P. D., (1994). Scavenging effect of methanolic extracts of peanut hulls on free-radical and active oxygen species, J. Agric. Food Chem. 42, 629-632.

Yen G C, Wu JY. 1999. Antioxidant and radical scavenging properties of extracts from Ganoderma tsugae. Food Chem. 65, 375-379.

Zheng W, Wang SY. 2001. Antioxidant activity and phenolic compounds in selected herbs. J. Agric. Food Chem. 49, 5165-5170. 